\title{
Сучасні аспекти
}

\section{терапевтичної тактики хворих на акантолітичний пемфігус}

\author{
А.E-C.E-C. Абдалла \\ ДУ «Інститут дерматології та венерології НАМН України»
}

\begin{abstract}
Резюме
У статті висвітлений огляд науково-медичної літератури щодо сучасних методів лікування хворих на акантолітичний пемфігус. Наведені приклади застосування біологічної, противірусної, імунологічної, екстракорпоральної, місцевої та інших видів терапії закордонних і вітчизняних авторів.
\end{abstract}

Ключові слова: акантолітичний пемфігус, системні глюкокортикостероїди, базова терапія, ад'ювантна терапія, місцева терапія.

DOI: 10.33743/2308-1066-2019-4-8-11

\section{Вступ}

Акантолітичний пемфігус (АП, акантолітична пухирчатка, справжня пухирчатка) - автоімунне захворювання шкірних покривів i/або слизових оболонок. Клінічним проявом його є утворення міхурів та ерозій. АП належить до групи особливо тяжких захворювань шкіри, які призводять до інвалідизації та навіть смерті [1]. Гістологічна картина формується внаслідок акантолізу з інтраепідермальним розташуванням міхура [12, 42]. Механізм акантолізу при пухирчатці складний і не до кінця зрозумілий [4]. Пошкодження десмосом внаслідок синтезу протеолітичних ферментів призводить до порушення їх функції, руйнації та як наслідок - акантолізу [4, 15].

Сучасні знання про патогенез автоімунних захворювань шкіри дали змогу визначити три основні антигенні структури, які є мішенню для імунної відповіді: десмосоми, напівдесмосоми та фібрили $[18,26]$. Антигенами при даній нозологічній одиниці є трансмембранні глікопротеїни десмосом - десмоглеїни, адгезуючі молекули кадгеринового типу та ін. [38, 44]. Фундаментом автоімунної реакції при АП є утворення IgG (субкласів $\mathrm{G}_{1}$ i $\mathrm{G}_{4}$ ) до десмоглеїнів ДСГ-1 (130 кДА) і ДСГ-3 (160 кДА). Циркулюючі автоантитіла до поверхневих протеїнів кератиноцитів пошкоджують структуру десмосом, а потім і їх функцію.

Етіологія даного дерматозу невідома, існують такі теоpii: атавістична [29]; неврогенна [41]; ензимна [33]; обмінна [19]; ендокринна [22]; вірусна (Lever W.F.) [36]; автоімунна - мала розвиток у період $60-70$-х років XX сторіччя. Зацікавленість дослідників з'явилась після публікацій робіт Beutner E.H. (1964; 1965; 1968), Jordon.Е. (1964; 1968), Chorzelski T.P. (1968; 1974), в яких автори продемонстрували наявність автоантитіл у сироватці крові хворих на пухирчатку. Пізніше теорія набула значимості завдяки експериментальним дослідженням B. Michel i K. Hashimoto, W. Lever y 1970 p.
На сьогодні існує чимало класифікацій бульозних дерматозів, які базуються на етіологічних, клініко-морфологічних, патогенетичних, генетичних і інших факторах. Сучасні дерматологи за клінічними, патогістологічними та імунохімічними ознаками поділяють АП на вульгарний (pemphigus vulgaris), вегетуючий (pemphigus vegetans), еритематозний, або себорейний (pemphigus erythematosus seu seborrhoicus), і листоподібний (pemphigus foliaceus) [10, $13,21,24]$.

Існують форми бульозного пошкодження шкіри, при якому булла (bulla) є основною ознакою захворювання. До таких нозологій відносять АП, бульозний епідермоліз, рубцюючий і бульозний пемфігоїд, токсичний епідермальний некроліз, герпетиформний дерматит Дюрінга тощо. Міхур як непостійну ознаку дерматозу можна спостерігати при бульозній формі токсидермії, багатоформній ексудативній еритемі, хворобі Дар'є, червоному плоскому лишаї та навіть піодермії [7, 17].

Клінічно початком АП є утворення в'ялих міхурів на видимо здоровій шкірі та слизових оболонках внаслідок акантолізу. Як правило, міхури швидко руйнуються, утворюючи болючі яскраво-червоні або вкриті білуватим нальотом ерозії з обривками епітелію по периферії (залишки покришки міхура) [9]. Ерозії кровоточать при дотику інструментами та прийомі їжі. Хворі відзначають болючість ерозій, неприємний запах з рота та гіперсалівацію, що погіршує загальний стан [3]. Тож в першу чергу такі хворі потрапляють до стоматологів та отоларингологів.

Терапія здатна зупинити процес автоагресії за рахунок пригнічення імунної відповіді та спрямована на автопротеїни кератиноцитів. Застосування імуносупресивної терапії дає можливість зберегти життя хворого працездатного віку та покращити його якість. На сьогодні основними препаратами для лікування хворих 
на пухирчатку залишаються глюкокортикостероїди (ГКС) та цитостатики. Хоча така терапія є агресивною та спричинює багато ускладнень, вона не має абсолютних протипоказань до застосування у хворих на АП, тому що лише ГКС та їх комбінація з цитостатиками запобігають летальним наслідкам [5].

Доза $\boldsymbol{\Gamma \boldsymbol { C }}$ підбирається індивідуально з урахуванням віку хворого, його маси тіла, поширеності патологічного процесу. Як правило, застосовують преднізолон або інші ГКС у перерахунку на еквівалент преднізолону: гідрокортизон, дексаметазон, бетаметазон, метилпреднізолон, тріамцинолон та ін. (табл. 1) [16]. Початкова терапевтична доза ГКС може бути середньою (80-120 мг/добу) або ударною (120-200 мг/добу). Лікування триває до припинення появи нових елементів висипу та епітелізації ерозій, зазвичай декілька тижнів. Регрес дерматозу є підставою для поступового зниження дози препаратів. Процес загоєння починається з ерозій на шкірі та завершується на слизових оболонках. Це слід враховувати під час спостереження та аналізу динаміки регресії дерматозу.

Цитостатичні препарати (азатіоприн, циклофосфамід, метотрексат, мікофенолат мофетил) призначають для підвищення комплаєнсу в комбінації з ГКС, а також з метою зниження доз ГКС [43]. Ці препарати не мають швидкого ефекту, на відміну від ГКС, тому їх застосовують у монотерапії вкрай рідко. Але ефект комбінованої терапії рівнозначний такому високих доз преднізолону (табл. 2) [39]. Доза цитостатичного препарату підбирається індивідуально, як і ГКС, та залежить від клінічної картини, тяжкості та поширеності патологічного процесу, віку хворого, його маси тіла, наявності супутніх захворювань [8]. Після досягнення ремісіі рекомендують призначати підтримувальну дозу протягом 2-4 міс [11].

$\mathrm{y}$ посібнику «Guideline on the Diagnosis and Treatment of Autoimmune Bullous Diseases - Pemphigus» від 2009 р., розробленому європейським дерматовенерологічним форумом, запропонована комбінована схема лікування АП (ГКС у дозі 1-1,5 мг/кг/добу та азатіоприн по 100 мг/добу), яку призначають відразу після встановлення діагнозу.

Допоміжними (ад’ювантними) лікарськими засобами є:

Імуноглобулін - знижує концентрацію автоантитіл у сироватці крові. За рахунок підвищеного їх катаболізму пригнічує агресію автоантитіл до антигенів - мішеней. Його

Таблиця 1. Дози ГКС еквівалентні 5 мг преднізолону

\begin{tabular}{|l|c|}
\hline \multicolumn{1}{|c|}{ Препарат } & Еквівалентна доза, мг \\
\hline Бетаметазон & 0,6 \\
\hline Тріамцинолон & 4 \\
\hline Дексаметазон & 0,75 \\
\hline Метилпреднізолон & 4 \\
\hline Гідрокортизон & 20 \\
\hline
\end{tabular}

Таблиця 2. Дози цитостатиків для терапії АП

\begin{tabular}{|l|c|}
\hline \multicolumn{1}{|c|}{ Препарат } & Доза \\
\hline Метотрексат & $10-50$ мг/тиж \\
\hline Азатіоприн & $1-3$ мг/кг/добу \\
\hline Циклоспорин & $5-8$ мг/кг/добу \\
\hline Мікофренолат мофетил & $150-200$ г/добу \\
\hline
\end{tabular}

призначають у разі відсутності ефекту від ГКС. Так, у дослідженнях Bystryn J.C. та Jiao D. зазначається, що після застосування імуноглобуліну внутрішньовенно в дозі 400 мг/кг/добу протягом 5 днів середню базову дозу ГКС вдалось знизити на 40\% за перші 3 тиж, а рівень автоантитіл у сироватці крові зменшився за 1-й тиждень на 59\%, за 2-й тиждень - близько 70\% [25, 30].

У 2011 р. лікарі Ahmed A.R., Gurcan H.M. у статті «Use of intravenous immunoglobulin therapy during pregnancy in patients with pemphigus vulgaris» поділились досвідом застосування ГКС у комбінації з імуноглобулінами: переваги такої тактики полягали в менш вираженій імуносупресивній дії та швидшому досягненні ремісії.

Нині проводять рандомізовані клінічні дослідження із застосування біологічної терапї. Ритуксимаб є першим i на сьогодні єдиним біологічним засобом, який застосовують закордонні колеги при АП. Механізм дії препарату у хворих на АП полягає в послабленні антиген-презентувальної функції В-клітин, зниженні формування автоантиген-специфічних В-клітин пам'яті, плазматичних клітин, виснаженні попередників плазматичних клітин, пригніченні синтезу антитіл та імунних комплексів [23]. Застосовують ритуксимаб внутрішньовенно краплинно в дозі 375 мг/кг на тиждень протягом 4 тиж на тлі імуносупресивної терапії. Через 6 міс курс рекомендують повторити. Таку терапію призначають хворим з тяжким перебігом дерматозу, резистентним до базисної терапії ГКС та цитостатиками [28, 34].

У публікаціях J Am Acad Dermatol від 2012 р. наводять досвід застосування інфліксимабу, етанерцепту та адалімумабу італійськими, чеськими та індійськими колегами. Вищезазначені препарати не отримали бажаних відзнак. Отже перевагу в лікуванні для отримання задовільного терапевтичного ефекту віддають ритуксимабу [27, 28].

\section{Екстракорпоральними методами терапіï} є екстракорпоральна фотохіміотерапія, плазмаферез і імуноабсорбція. Переваги такого лікування наведені в працях Грандо С.А. (1988), Yamada H., Yamaguchi H, Takamori K. (1997), Кільдюшевского A.В. та Молочкова B.A. (2008), Meyersburg D., Schmidt E., Kasperkiewicz M. (2012). Використання цих методів дає змогу зменшити тривалість застосування ударних чи середніх доз ГКС, що мінімізує їх побічні ефекти [37].

Комбінація ГКС і плазмаферезу дає можливість досягти більш стійкої та тривалої ремісії. Даний метод сприяє елімінації циркулюючих автоантитіл IgG і імунних комплексів, які відіграють важливу роль у патогенезі АП [31].

Iмуноабсорбиія із застосуванням специфічних і неспецифічних імуносорбентів - метод відомий білыш ніж 40 років, але є новим у лікуванні автоімунних захворювань. Він забезпечує видалення з плазми крові хворого імуноглобулінів, комплементу, інтерлейкінів, простагландинів і циркулюючих імунних комплексів [37].

Екстракорпоральна фотохіміотерапiя направлена на пригнічення продукції автоантитіл шляхом опромінення клітин крові ультрафіолетовим промінням спектра А (ПУВА-терапія) поза організмом людини. Механізм дії полягає у пригніченні продукції автоантитіл В-лімфоцитами [6]

Противірусна терапія - актуальна за умов тяжкого перебігу АП та відсутності адекватної відповіді на базисну терапію - зазначають італійські автори A.V. Marzano, A. Tourlaki, V. Merlo, D. Spinelli, L. Venegoni, C. Crosti у статті «Herpes Simplex Virus Infection and Pemphigus» 
від 2009 р. з Istituto di Scienze Dermatologiche, Universit degli Studi di Milano, Fondazione IRCCS Ospedale Maggiore Policlinico, Mangiagalli e Regina Elena, Milano, Italy. У науковій літературі багато дослідників відзначали роль вірусного агента як обтяжливого фактора в перебігу цього дерматозу [32]. Тому застосування ацикловіру обгрунтоване в разі торпідного та рефрактерного перебігу АП за умов асоціації з вірусом простого герпесу (ВПГ) [40]. Зазначено покращення шкірного процесу після призначення курсу в дозі 1200 мг/добу.

У праці Балтабаєва М.К., д.м.н., професора, завідувача кафедри дерматовенерології та фтизіатрії КиргизькоРосійського слав'янського університету ім. Б.М. Єльцина, у 2015 р. наведені результати обстеження хворих на АП. Було виявлено підвищення титру антитіл до цитомегаловірусної (ЦМВ) інфекції в периферійній крові та наявність фрагментів ДНК ЦМВ у вогнищах уражень. Це обгрунтовує призначення ганацикловіру в комплексній терапії хворих на АП з метою пригнічення реплікації вірусу. У ході клінічного спостереження хворі на АП відзначали хорошу переносимість, зменшення загальної слабкості та швидкої стомлюваності, прискорення епітелізації ерозій. Колеги відзначили, що після курсу лікування ганацикловіром поріг підтримувальної дози ГКС вдалося знизити до мінімальних цифр у 7 з 10 хворих. [2].

Часте виявлення ВПГ 1-го та 2-го типів, вірусу герпесу людини 6-, 7-, 8-го типів, ЦМВ, вірусу Епштейна-Барр, вірусу varicella zoster, вірусу гепатиту В у хворих з торпідним перебігом обумовлює призначення антивірусної терапії.

Експериментальний метод терапї: натепер тривають клінічні дослідження щодо застосування пептидів (агоністи пептиду Dsg3) в терапії АП. Про їх безпечне та ефективне застосування у хворих на АП повідомляють колеги з Японії [35].

\section{Список літератури}

1. Адаскевич В.П., Козловская В.В. Пузырчатка: эпидемиология, патогенез, клинические проявления, диагностика. Медицинские новости (Минск). 2008. № 16. С. 14-9.

2. Балтабаев М.К., Балтабаев А.М. Способ лабораторной диагностики истинной акантолитической пузырчатки. Патент на изобретение № 383 от 30.01 .2015 года. Интеллектуалдык енчик (Интеллектуальная собственность). Официальный бюллетень, Бишкек, 2015, № 1. 3. Боровский, Е.В., Машкилейсона А.Л. Заболевания слизистой оболочки полости рта и губ. Практическое руководство. М.: МЕДпресс, 2001. С. 182-183.

4. Вольф К., Голдсмит Л.А., Кац С.И. и др. Дерматология Фицпатрика в клинической практике: в 3 т. / пер. с англ.; общ. ред. акад. А. А. Кубановой. М: Издательство Панфилова; 5. К. Лаборатория знаний, 2012. Т. 1. С. 487-565.

5. Каламкарян А.А., Трофимова Л.Я., Хапилова В.И. Иммунодепрессанты в комплексой терапии пузырчатки. Вестн. дерматол. и венерол. 1979. № 12. С. 28-32.

6. Кильдюшевский А.В., Молочков В.А., Карзанов О.В. Динамика клеточного иммунитета в процессе экстракорпоральной фотохимиотерапии у больных истинной пузырчат7. Росс. журн. кожн. вен. бол. 2008. № 4. С. 71-76.

7. Кубанов А.А., Знаменская Л.Ф., Абрамова Т.В., Свищенко С.И. К вопросам диагностики истинной (акантолитической) пузырчатки. Вестник дерматологии и венерологии

8. Кубанова А.А., Самсонов В.А., Хапилова В.И., Матушевская Е.В. Сандиммун в терапии
9. больных истинной пузырчаткой. Вестн. дерматол. и венерол. 1994. № 6. С. 42

рта. Нижний Новгород,

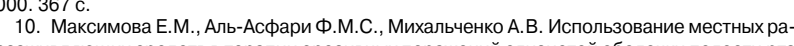
нозаживляющих средств в терапии эрозивных поражений слизистой оболочки полости рта при вульгарной пузырчатке. Вестник Волгоградского государственного медицинского уни(2017. № 3(63). С. 71-74.

11. Аутоантитела и аутоантигены при пузырчатке и пемфигоиде / Е.В. Матушевская, А. Кубанова, В.А. Самсонов и др. Вестн дерматол и венерол. 1995;5:28-33.

12. Матушевская Е.В., Свирщевская Е.В., Кубанова А.А. Иммунология вульгарной пузырчатки и возможный механизм формирования заболевания. Вестн дерматол и венерол. 13. № 2. С. 25-28.

13. Махнева Н.В. Клинико-морфологические и иммунологические аспекты в ранней диагностике и лечении аутоиммунных буллезных дерматозов. Автореф. дисс. ... докт. мед. 14. Рабинович

14. Рабинович О.Ф., Рабинович И.М., Разживина Н.В. Пузырчатка слизистой оболочки рта. Пародонтология. 2006 (37). № 1. С. 34.

15. Самцов, А.В., Белоусова И.Э. Буллезные дерматозы. СПб.: КОСТА. 2012. 144 с.

16. Соколовский Е.В. Пузырные дерматозы. Псориаз. Современные методы лечения. 17. КБиблиотека врачадерматовенеролога". Выпуск 3: СПб: СОТИС. 1999. 134 с.

А.С. Алленова, А.А. Лепехова. Российский журнал кожных и венерических болезней. А.С. Алленова, А.А. Ле

18. Толмачева С.М., Жданова М.Д., Тиунова Н.В. Клинический случай акантолитической пузырчатки в практике врача-стоматолога. Стоматологический форум. 2015. № 4. С. 86. гарной пузырчатки. Проблемы современной науки и образования. 2016. № 8. С. 149-151.
Велике значення в лікувальній програмі хворих на АП відводять місцевому догляду. Вогнища ураження шкірних покровів і слизових оболонок потребують регулярної санації. Для запобігання приєднанню вторинної інфекції застосовують антисептичні та дезінфікуючі розчини: 3\% перекис водню, 0,05\% перманганат калію; аніліновий барвник - $1 \%$ водний розчин піоктаніну; антибактеріальні засоби: присипки ксероформу, фузидієвої кислоти, бацитрацину цинку та неоміцину сульфату тощо; репаративні препарати: обліпихова олія, розчин ромашки, олія шипшини. Це сприяє швидкій епітелізації вогнищ ураження. Санація ерозивних дефектів на слизових оболонках статевих органів проводиться із застосуванням ванночок з антибактеріальними та дезінфікуючими розчинами, також використовують водні анілінові барвники та ранозагоювальні засоби [20]. Загоєнню слизової ротової порожнини сприяє регулярне полоскання дезінфікуючими розчинами після прийомів їжі та між ними, застосування знеболювальних дентальних гелів: 0,5\% новокаїн, $2 \%$ лідокаїну гідрохлорид; водного анілінового барвника та засобів з репаративними властивостями [14].

\section{Висновки}

Аналіз наукової літератури свідчить, що перевага в лікуванні АП надається базовій імуносупресивній терапіі - ГКС і цитостатикам. Лікувальна тактика спрямована на нейтралізацію та елімінацію автоантитіл, профілактику вторинної інфекції, репарацію шкірних покривів і слизових оболонок. Станом на сьогодні застосування допоміжних методів лікування (противірусних, біологічних препаратів, імуноглобулінів тощо) перебуває в стадії дослідження. Допоміжні методи лікування прискорюють загоєння вогнищ ураження, зменшують побічні явища ГКС за рахунок зниження доз препаратів базової терапії, забезпечують тривалу ремісію.

\section{References}

1. Adaskevich VP, Kozlovskaya W. Puzyrchatka: epidemiologiya, patogenez, klinicheskiye proyavleniya, diagnostika [Pemphigus: epidemiology, pathogenesis, clinical manifestations, diagnosis]. Medicinskie novosti (Minsk). 2008;16:14-9.

2. Baltabaev MK, Baltabaev AM. Sposob laboratornoj diagnostiki istinnoj akantoliticheskoj puzyrchatki [A method for laboratory diagnosis of true acantholytic pemphigus]. Patent na izobretenie № 383 ot 30.01.2015 goda. Intellektualdyk menchik (Intellektualnaya sobstvennost). Oficialnyj byulleten, Bishkek, 2015; 1

3. Borovskij EV, Mashkilejsona AL. Zabolevaniya slizistoj obolochki polosti rta i gub. Prakticheskoe kovodstvo [Diseases of the oral mucosa and lips]. M.: MEDpress, 2001; 182-183.

4. Wolff K, Goldsmith LA, Katz SI, et al. Dermatologiya Fitspatrika v klinicheskoy praktike [Fitzpatrick's dermatology in general medicine]: v 3 t. Per. s angl.; obshh. red. akad. A.A. Kubanovoj.

5. Izatel'stvo Panfllova, BINOM. Laboratorija znanij. 2012,1;487-565.

. Kalamkaryan AA, Trofimova LYa, Khapilova VI. Immunodepressanty v kompleksnoy terapii puzyrchatki [lmmunosuppressants in the treatment of pemphigus]. Vestn Dermatol Venereol. 979;12:28-32.

6. Kil'dyushevskiy AV, Molochkov VA, Karzanov OV. Dinamika kletochnogo immuniteta v protsesse nity in the process of extracorporeal photochemotherapy in patients with true pemphigus]. Rus J Skin nity in the process of extracorporeal photochemotherapy in patients with true pemphigus]. Rus J Skin
Sex Transmit Dis. 2008:4:71-76.

7. Kubanov AA, Znamenskaya LF, Abramova TV, Svishchenko SI. K voprosam diagnostiki istinnoy (akantoliticheskoy) puzyrchatki [Revisited diagnostics of true (acantholytic) pemphigus]. Vestnik Dermatologii i Venerologii. 2014;6:121-130.

8. Kubanova AA, Samsonov VA, Khapilova VI, Matushevskaya EV. Sandimmun v terapii bol'nykh istinnoy puzyrchatkoy [Sandimmune in the treatment patients of true pemphigus]. Vestn Dermatol Venerol. 1994;6:42.

9. Lukinih LM. Zabolevaniya slizistoi obolochki polosti rta [Oral mucosal diseases]. Nijnii Novgorod, 2000. $367 \mathrm{p}$

10. Maksimova EM, FMSAl-Asfari, Mihalchenko AV. Ispolzovanie mestnih ranozajilyayuschih sredstv v terapii erozivnih porajenii slizistoi obolochki polosti rta pri vulgarnoi puzirchatke [The use of local Wound healing agents in the treatment of erosive lesions of the oral mucosa with pemphigus vulgaris. estnik Volgogradskogo gosudarstvennogo medicinskogo universiteta. 2017;3(63):71-74. 11. Matushevskaya EV, Kubanova AA, Samsonov VA, et al. Autoantitela i autoantigeny pri
a puzyrchatke i pemfigoide [Autoan

12. Matushevskaya EV, Svirshchevskaya EV, Kubanova AA, et al. Immunologiya vul'garnoy
(m) puzyrchatki i vozmozhnyy mekhanizm formirovaniya zabolevaniya [Immunology of vulgar pemphigus and a possible mechanism for the formation of the disease]. Vestn Dermatol Venereol. 1996;2:25-28.

13. Mahneva NV. Kliniko-morfologicheskie i immunologicheskie aspekti v rannei diagnostike i lechenii autoimmunnih bulleznih dermatozov [Clinical, morphological and immunological aspects in the early diagnosis and treatment of autoimmune bullous dermatoses]. Avtoref. Diss. dokt. med. nauk. early diagnosis and treatment of
Moscow, 2009; 55 . (in Russian)

14. Rabinovich OF, Rabinovich IM, Razjivina NV. Puzirchatka slizistoi obolochki rta [Pemphigus oral mucosa]. Parodontologiya. 2006(37);1:34.

15. Samcov AV, Belousova IE. Bullyoznye dermatozy [Bullous dermatoses]. SPb.: KOSTA, 
20. Чеботарев В.В., Байда А.П. Руководство для врачей общей практики (семейных врачей) по дерматовенерологии. Ставрополь, 2009. С. 164

21. Чеботарев В.В., Сирак А.Г., Аль-асфари Ф.М.С., Сирак В. Обыкновенная пузырчатка: особенности терапии в полости рта. Медицинский вестник Северного Кавказа. 2014. № 3. С. 215-217.

22. Чистякова И.А., Лапина Е.Ю. Роль своевременной диагностики вульгарной пузырчатки, начинающейся со слизистой оболочки полости рта. Вестник последипломного медицинского образования. 2012. № 2. С. 11-14.

23. Browning J.L. B cells move to centre stage: novel opportunities for autoimmune disease atment. Nat Rev Drug Discov. 2006. 5. P. 564-576.

24. Berookhim B., Fischer H.D., Weinberg J.M. Treatment of recalcitrant pemphigus vulgaris whit the tumor necrosis factor alpha antagonist etanercept, Cutis. 2014. № 4(74). P. 245-247. 25 . Bystryn J.C., Jiao D. IVIg selectively and rapidly decreases circulating pathogenic autoantibodies in pemphigus vulgaris. Autoimmunity. 2006. 39 (7). P. 601-607.

26. Fructose and pectin detection in fruit-based food products by surface-enhanced ra26. Fructose and pectin detection in fruit-based food products by surface-enhanced raP. 839-842.

27. Cianchini G., Lupi F., Masini C. Therapy with rituximab for autoimmune pemphigus: results from a single-center observational study on 42 cases with long-term follow-up. J Am Acad Dermatol. 2012. V.67. N4. P. 617-622.

28. Craythorne E. E., Mufti G., DuVivier A.W. Rituximab used as a first-line single agent in the reatment of pemphigus vulgaris. J Am Acad Dermatol. 2011. V. 65. P. 1064-1065.

29. Fellner M.J. Sapadin A.N. Current therapy of pemphigus vulgari. Mt. Sinai J. Med. 2016. № 68. P. 268-278.

30. Gürcan H.M., Jeph S., Ahmed A.R. Intravenous immunoglobulin therapy in autoimmune f the evidence for its efficacy and safety. Am J Clin mucocutaneous blistering diseases: a review of the evidence for its efficacy and safety. Am J Clin
Dermatol. 2010. V. 11, N 5. P. 315-326.

and Database. Elsevier Science, 2004. http://ww xpharm.

32. Iraji F., Faghihi G., Siadat A.H. The efficacy of acyclovir in treatment of the pemphigus vulgaris. J Res Med Sci. 2013 Nov; 18 (11). P. 976-8.

33. Jan A. A novel homozygous variant in the dsp gene underlies the first case of non-syndromic form of alopecia. Archives of Dermatological Research. 2015. № 9(307). P. 793-801. 34. Kanwar A.J., Vinay K. Rituximab in pemphigus. Indian J Dermatol Venereol Leprol. 2012. V. 78 , N6. P. 671-676.

35. Koga H., Tsuruta D., Ohyama B. Desmoglein 3, its pathogenecity and a possibility for therapeutic target in pemphigus vulgaris. Expert Opin Ther Targets. 2013. V. 17, N3. P. 293-306. 36. Lever W.F., Schaumburg-Lever G. Treatment of pemphigus vulgaris. Results obtained in 84 patients between 1961 and 1982. Arch. Dermatol. 2014. № 1(120). P. 44-47.

37. Meyersburg D. Schmidt E., Kasperkiewicz M., Zillikens D. Immunoadsorption in Dermatology. Ther Apher Dial. 2012. N16 (4). P. 311-320.

38. Mucosal pemphigus vulgaris anti-Dsg3 $\mathrm{IgG}$ is pathogenic to the oral mucosa of humanized Dsg3 mice / D.A. Culton [et al.]. Journal of Investigative Dermatology. 2015. Vol. 135(6). P. $1590-1597$

39. Olszewska M., Kolacinska-Strasz Z. Sulej J. Efficacy and safety of cyclophosphamide, azathioprine, and cyclosporine (ciclosporin) as adjuvant drugs in pemphigus vulgaris. Am J Clin Dermatol. 2007. V. 8 (2). P. 85-92.

40. Refractory pemphigus vulgaris associatedwith herpes infection: case report and review/ M.L. Brandao, N.C. Fernandes, D.P. Batista, N. Santos. Rev Inst Med Trop Sao Paulo. 2011 MarApr. V. 53 (2). P. 113-7.

41. Mean platelet volume and eosinophilia relationship in patients with bullous pemphigoid / E.N. Rifaioglu, B.B. Sen, O. Ekiz, A.C. Dogramaci. Platelets. 2014. № 4(25). P. 264-267.

42. Schiltz J.R., Michel B. Production of epidermal acantholysis in normal humanskin in vitro by the lgG fraction from pemphigus serum. J Invest Dermatol. 1976. V. 67 (2). P. 254-260. 43. Schmidt E., Zillikens D. The diagnosis and treatmentof autoimmune blistering skin diseases. Dtsch rztebl Int. 2011. V. 108. P. 399-405.

44. Tsang S.M., Brown L., Lin K., Liu L. Non-junctional human desmoglein 3 acts as an upstream regulator of Src in E-cadherin adhesion, a pathway possibly involved in the pathogenesis of pemphigus vulgaris. The Journal of Pathology. 2012. Wiley Online Library//https://onlinelbrary.wiley.com/doi/abs/10.1002/path.3982
16. Sokolovskii EV. Puzyrnye dermatozy. Psoriaz. Sovremennye metody lecheniya [Bullous der. Psoriasis Modern treatments]. Seriya «Biblioteka vrachadermatovenerologa”. Vypusk 3 SPb: SOTIS, 1999; $134 \mathrm{p}$

17. Tkachenko SB, Teplyuk NP, Allenova AS, Lepehova AA. K voprosu o klassifikacii bulleznih dermatozov [On the classification of bullous dermatoses]. Rossiiskii jurnal kojnih i venericheskih bolez2015;18(2):11-14.

18. Tolmacheva SM, Jdanova ML, Tiunova NV. Klinicheskii sluchai akantoliticheskoi puzirchatk praktike vracha stomatologa [A clinical case of acantholytic pemphigus in the practice of a dentist] 2015;4:86.

19. Hamaganova IV, Malyarenko EN, Vasileva AYu, etal. Oshibkiv diagnostike vulgarnoj puzyrchatk istakes in the diagnosis of pemphigus vulgaris]. Problemy sovremennoj nauki i obrazovaniya. 2016;8:149-151.

20. Chebotarev W, Bajda AP. Rukovodstvo dlya vrachej obshej praktiki (semejnyh vrachej) po dernerologii. Stavropol, 2009. 164 p.

21. Chebotarev W, Sirak AG, F.M.S.Al-Asfari, Sirak V. Obyknovennaya puzyrchatka: osoben(

Kavkaza. 2014;3:215-217.

22. Chistyakova IA, Lapina EYu. Rol svoevremennoj diagnostiki vulgarnoj puzyrchatki, nachinayushejsya so slizistoj obolochki polosti rta [The role of timely diagnosis of vulgar pemphigus, starting with the jyal mucosa]. Vestnik poslediplomnogo medicinskogo obrazovaniya. 2012;2:11-14.

23. Browning JL. B cells move to centre stage: novel opportunities for autoimmune disease treatment. Nat Rev Drug Discov. 2006;5:564-576.

24. Berookhim B, Fischer HD, Weinberg JM. Treatment of recalcitrant pemphigus vulgaris whit the umor necrosis factor alpha antagonist etanercept. Cutis. 2014;74(4):245-247.

25 . Bystryn JC, Jiao D. IVIg selectively and rapidly decreases circulating pathogenic autoantibodsin pemphigus vulgaris. Autoimmunity. 2006;39(7):601-607.

26. Camerlingo C, Portaccio M, Lepore M, Tate R, Delfino I. Fructose and pectin detection in fruitbased food products by surface-enhanced raman spectroscopy Sensors. 2017;17(4):839-842.

27. Cianchini G, Lupi F, Masini C, et al. Therapy with rituximab for autoimmune pemphigus: results from a single-center obsenational study on 42 cases with long-term follow-up. J Am Acad Dermato 2012;67(4):617-622.

28. Craythorne EE, Mufti G, DuVivier AW. Rituximab used as a first-line single agent in the treatment of pemphigus vulgaris. J Am Acad Dermatol. 2011:65:1064-1065.

29. Fellner MJ, Sapadin AN. Current therapy of pemphigus vulgaris. Mt. Sinai J. Med. 2016;68:268 278.

30. Gürcan HM, Jeph S, Ahmed AR. Intravenous immunoglobulin therapy in autoimmune mucocutaneous blistering diseases: a review of the evidence for its efficacy and safety. Am J Clin Dermatol. 2010;11(5):315-326.

31. Hawayek L, Mutasim D. Pemphigus vulgaris. xPharm Online Pharmacology Reference and atabase. Elsevier Science. 2004; http: //uww. xpharm.com.

32. Iraji F, Faghihi G, Siadat AH. The efficacy of acyclovir in treatment of the pemphigus vulgaris. Res Med Sci. 2013 Nov; 18(11):976-978.

33. Jan A, Ahmad W, Basit S, et al. A novel homozygous variant in the dsp gene underlies the first case of non-syndromic form of alopecia. Archives of Dermatological Research. 2015;307(9):793-801. 2012;78(6):671-676

35. Koga H, Tsuruta D, Ohyama B. Desmoglein 3, its pathogenecity and a possibility for therapeutic target in pemphigus vulgaris. Expert Opin Ther Targets. 2013;17(3):293-306.

36. Lever WF, Schaumburg-Lever G. Treatment of pemphigus vulgaris. Results obtained in $84 \mathrm{pa}$ ents between 1961 and 1982. Arch. Dermatol. 2014;120(1):44-47.

37. Meyersburg D, Schmidt E, Kasperkiewicz M, Zillikens D. Immunoadsorption in Dermatology. Ther Apher Dial. 2012;16(4):311-320.

38. Culton DA, et al. Mucosal pemphigus vulgaris anti-Dsg3 IgG is pathogenic to the oral mucosa of humanized Dsg3 mice. Journal of Investigative Dermatology. 2015;135(6):1590-1597.

39. Olszewska M, Kolacinska-Strasz Z. Sulej J. Efficacy and safety of cyclophosphamide, azathioprine, and cyclosporine (ciclosporin) as adjuvant drugs in pemphigus vulgaris. Am J Clin Dermato. 2007;8(2):85-92.

40. Brandao ML, Fernandes NC, Batista DP, Santos N. Refractory pemphigus vulgaris associatedwith herpes infection: case report and review. Rev Inst Med Trop Sao Paulo. 2011 Mar-Apr; 53(2):113117.

41. Rifaioglu EN, Sen BB, Ekiz O, Dogramaci AC. Mean platelet volume and eosinophilia relationship in patients with bullous pemphigoid. Platelets. 2014;25(4):264-267.

42. Schiltz JR, Michel B. Production of epidermal acantholysis in normal humanskin in vitro by the Ig G fraction from pemphigus serum. J Invest Dermatol. 1976;67(2):254-260.

43. Schmidt $E$, Zillikens $D$. The diagnosis and treatmentof autoimmune blistering skin diseases. Dtsch rztebl Int. 2011;108:399-405.

44. Tsang SM, Brown L, Lin K, Liu L, Piper K, O'Toole EA, Grose R, Hart IR, Garrod DR, Fortune F, Wan $\mathrm{H}$. Non-junctional human desmoglein 3 acts as an upstream regulator of Src in E-cadherin adheson, a pathway possibly involved in the pathogenesis of pemphigus vulgaris. The Journal of Pathology. 2012. Wiley Online Library//https://onlinelibrary.wiley.com/doi/abs/10.1002/path.3982

\title{
СОВРЕМЕННЫЕ АСПЕКТЫ ТЕРАПЕВТИЧЕСКОЙ ТАКТИКИ БОЛЬНЫХ АКАНТОЛИТИЧЕСКИМ ПЕМФИГУСОМ
}

\author{
А.Э-С.Э-С. Абдалла
}

ГУ «Институт дерматологии и венерологии НАМН Украины»

\section{Резюме}

В статье представлен обзор научно-медицинской литературы по современным методам лечения больных акантолитическим пемфигусом. Приведены примеры применения биологической, противовирусной, иммунологической, экстракорпоральной, местной и других видов терапии зарубежными и отечественными авторами.

Ключевые слова: акантолитический пемфигус, системные глюкокортикостероиды, базовая терапия, адьювантная терапия, местная терапия.

\section{MODERN ASPECTS OF THERAPEUTIC TACTICS OF PATIENTS WITH ACANTHOLYTIC PEMPHIGUS}

\author{
A.E-S.E-S. Abdalla
}

$S E$ «Institute of Dermatology and Venereology of NAMS of Ukraine»

Abstract

The article provides an overview of the scientific and medical literature of modern methods of treatment of patients with acantholytic pemphigus. Examples of biological, antiviral, immunological, extracorporeal, local and other therapy of foreign and domestic colleagues are given Key words: acantholytic pemphigus, systemic glucocorticosteroids, basic therapy, adjuvant therapy, local therapy.

Відомості про автора:

Абдалла Алія Ель-Саед Ель-Седик - аспірант відділу дерматології, інфекційних та паразитарних захворювань шкіри ДУ «/нститут дерматології та венерології НАМН України».

ORCID ID: https://orcid.org/0000-0002-6180-549X 